University of Nebraska - Lincoln

DigitalCommons@University of Nebraska - Lincoln

Michigan Bovine Tuberculosis Bibliography and

Database

Wildlife Disease and Zoonotics

1995

\title{
Bovine Tuberculosis in a Free-ranging Mule Deer (Odocoileus hemionus) from Montana
}

Jack Rhyan

U.S. Department of Agriculture, Animal and Plant Health Inspection Service, Veterinary Services, National Veterinary Services Laboratories, P.0. Box 844, Ames, lowa

Keith Aune

Montana Department of Rsh, Wildlife and Parks, Research and Technical Services Bureau, Fish, Wildlife and Parks Building, Montana State University Campus, Bozeman, Montana 59715, USA;

Brian Hood

Montana Department of Rsh, Wildlife and Parks, Research and Technical Services Bureau, Fish, Wildlife and Parks Building, Montana State University Campus, Bozeman, Montana 59715, USA;

Ryan Clarke

U.S. Department of Agriculture, Animal and Plant Health Inspection Services, Veterinary Services, 2206 Green Valley Drive, Billings, Montana

Janet Payeur

U.S. Department of Agriculture, Animal and Plant Health Inspection Service, Veterinary Services, National Veterinary Services Laboratories, P.0. Box 844, Ames, lowa

Sellowe this and additionalworks at: https://digitalcommons.unl.edu/michbovinetb

Part of the Veterinary Medicine Commons

Rhyan, Jack; Aune, Keith; Hood, Brian; Clarke, Ryan; Payeur, Janet; Jamagin, Jerald; and Stackhouse, Larry, "Bovine Tuberculosis in a Free-ranging Mule Deer (Odocoileus hemionus) from Montana" (1995).

Michigan Bovine Tuberculosis Bibliography and Database. 102.

https://digitalcommons.unl.edu/michbovinetb/102

This Article is brought to you for free and open access by the Wildlife Disease and Zoonotics at DigitalCommons@University of Nebraska - Lincoln. It has been accepted for inclusion in Michigan Bovine Tuberculosis Bibliography and Database by an authorized administrator of DigitalCommons@University of Nebraska Lincoln. 


\section{Authors}

Jack Rhyan, Keith Aune, Brian Hood, Ryan Clarke, Janet Payeur, Jerald Jamagin, and Larry Stackhouse 


\section{Bovine Tuberculosis in a Free-ranging Mule Deer (Odocoileus hemionus) from Montana}

Jack Rhyan,' Keith Aune,, Brian Hood, ${ }^{2}$ Ryan Clarke, Janet Payeur,' Jerald Jarnagin,' and Larry Stackhouse, ${ }^{\prime} \mathrm{IJ}$.S. Department of Agriculture, Animal and Plant Health Inspection Service, Veterinary Services, National Veterinary Services Laboratories, P.O. Box 844, Ames, lowa 50010, USA; ${ }^{2}$ Montana Department of Fish, Wildlife and Parks, Research and Technical Services Bureau, Fish, Wildlife and Parks Building, Montana State University Campus, Bozeman, Montana 59715, USA; ${ }^{3}$ U.S. Department of Agriculture, Animal and Plant Health Inspection Services, Veterinary Services, 2206 Green Valley Drive, Billings, Montana 59102, USA; “ Montana Department of Livestock, Veterinary Diagnostic Laboratory, P.O. Box 997, Bozeman, Montana 59771, USA

ABSTRACT: A survey of 41 mule deer (Odocoileus hemionus) and three white-tailed deer (O. virginianus) for bovine tuberculosis was conducted on a Montana (USA) cattle ranch from 2 November 1993 through January 1994. Gross and microscopic lesions typical of tuberculosis were present in tonsil and lymph nodes of the head, thorax, and abdomen of one adult female mule deer. Additionally, a single microgranuloma considered morphologically suggestive of tuberculosis was present in one lymph node of the head of a second mule deer. Mycobacterial isolates from lymph nodes of the head and thorax of the first deer were identified as $\mathrm{Myco}$ bacterium bovis.

Key words: Mule deer, Odocoileus hemionus, tuberculosis, Mycobacterium bovis, game farm, pathology.

Prior to 1980, there were few reported cases of bovine tuberculosis in cervids of North America (Stumpff, 1982). In the early 1980's, Mycobacterium bovis infection was discovered in captive elk in North and South Dakota (Stumpff, 1982). A concurrent epizootic of bovine tuberculosis in 21 captive bison (Bison bison) herds was traced back to one of the infected elk herds which shared premises with bison (Essey and Stumpff, 1985).

Since 1989 , tuberculosis caused by $M$. bovis has been detected in captive cervid herds in eight states in the USA and three Canadian provinces (Essey and Koller, 1994). Surveillance and control efforts for bovine tuberculosis in captive cervids currently are underway in both countries.

In April 1993, gross and microscopic lesions consistent with bovine tuberculosis were found in a captive elk (Cervus elaphus nelsoni) from a southcentral Montana (USA) game ranch $\left(45^{\circ} 55^{\prime} \mathrm{N}\right.$, $107^{\circ} 32^{\prime} \mathrm{W}$ ), and $M$. bovis was isolated from tissue specimens from the animal (J. Payeur, unpubl.). The captive elk herd totaled approximately 150 animals and was confined to two pastures totaling $1,050 \mathrm{ha}$, and a 650 ha shooter pen where fee-based hunting was conducted, respectively. The shooter pen also contained other captive ungulates including 16 bison, 19 pronghorn (Antilocapra americana), and less than 10 mule deer (Odocoileus hemionus). A single, maintained, $3.5 \mathrm{~m}$ woven wire fence surrounded each pasture and no escapes of captive ungulates were reported by the ranch manager. There was evidence of fence penetration by coyotes (Canis latrans). Subsequent to the discovery of tuberculosis, 12 elk from the main herd and the shooter pen were found positive on a single cervical tuberculin skin test (Anonymous, 1994) and were killed by gunshot and necropsied. Gross lesions were observed in 11 of the elk. Specimens from grossly visible lesions, mesenteric lymph nodes, and lymph nodes of the head and thorax were collected. Specimens were bisected and placed in 10 percent neutral buffered formalin and saturated sodium borate transport solution. Specimens were shipped to the National Veterinary Service Laboratory, Ames, Iowa, for histopathology and mycobacterial culture (Payeur et al., 1993). On histopathologic examination, grossly observed lesions were morphologically typical of tuberculosis. Culture results from all 12 elk were positive for M. bovis (R. Clarke, pers. comm.) Because of concern for possible spread of tuberculosis from infected game farms to 
native wildlife, a surveillance project examining cervids from land adjacent to the game ranch was conducted.

From 2 November 1993 through January 1994,41 mule deer and three whitetailed deer (Odocoileus virginianus) were examined from a cattle ranch adjacent to the infected game ranch. Animals were killed by hunters or shot by Montana Department of Fish, Wildlife and Parks (MDFWP) personnel. Tonsils, lymph nodes of the head, and thoracic and abdominal viscera were examined.

Tissue specimens included lung, palatine tonsils, and the following lymph nodes: medial and lateral retropharyngeal, parotid, mandibular, mediastinal, tracheobronchial, hepatic, and mesenteric. These were collected, divided, and frozen or placed in $10 \%$ neutral buffered formalin. Formalin-fixed tissues were sent to the $\mathrm{Na}$ tional Veterinary Services Laboratories (NVSL) and the Montana Veterinary Diagnostic Laboratory (MVDL). They were embedded in paraffin, sectioned at $5 \mu \mathrm{m}$, and stained with hematoxylin and eosin (HE). Additional sections from tissues with lesions suggestive of tuberculosis were stained by the fuchsin-methylene blue procedure of Henry and Cassidy (1966) and examined for the presence of acid-fast bacilli. Frozen specimens of tonsils, lymph nodes, and lungs were sent to the NVSL for mycobacterial isolation attempts by the methods of Payeur et al. (1993).

At necropsy, lesions were observed in two adult female mule deer. Deer 1 had grossly visible lesions in hepatic, thoracic, and retropharyngeal lymph nodes. Lesions varied in size from 1 to $8 \mathrm{~mm}$, were paleyellow, and were gritty on incision. The largest lesions were in the right tracheobronchial lymph node and focally protruded from the capsular surface. Lesions were not found in the lungs. Small $(2 \mathrm{~mm})$, yellow, gritty lesions also were present in three lymph nodes of the head from deer 2. No other gross lesions were noted. On histologic examination, lesions morphologically consistent with tuberculosis were present in sections of palatine tonsil, retropharyngeal lymph nodes, thoracic lymph nodes, and a hepatic lymph node from deer 1. Lymph node lesions consisted of small to large, irregular areas of caseous necrosis surrounded by moderate numbers of epithelioid macrophages, giant cells, and scant to moderate collagenous connective tissue. Mineralized material was scattered in the necrotic areas and surrounding macrophages in some of the lesions. The tonsilar lesion lacked mineralization and had numerous giant cells. Many giant cells contained numerous nuclei reminiscent of giant cells associated with $M$. bovis lesions in sika deer (Cervus nippon) (Rhyan and Saari, 1995). Rare, acid-fast bacilli were present in the necrotic material, macrophages, and giant cells of all lesions. In addition, the hepatic lymph node had marked autolytic changes with numerous, large bacilli in portions of the lesion. These bacilli were interpreted as saprophytic organisms.

Microscopically, lymph node lesions from deer 2 consisted of multifocal pyogranulomas containing Splendore-Hoeppli material and were surrounded by abundant collagenous connective tissue. These lesions were considered characteristic of actinomycosis or actinobacillosis.

Additionally, a single microgranuloma consisting of a small, central area of caseous necrosis surrounded by a moderate number of epithelioid macrophages and giant cells was noted in one lymph node from the head of a third deer. The lesion was considered suggestive of tuberculosis, but no acid-fast bacilli were demonstrated.

Mycobacterium bovis was isolated and identified by the methods of Payeur et al. (1993) from pooled lymph node specimens from the head and from pooled thoracic lymph node specimens from deer 1 . Mycobacterial cultures from lymph nodes of the head and thorax from all other deer were negative.

Reports of tuberculosis in free-ranging cervids in the continental USA are limited to two white-tailed deer in 1933 (Levine, 
1934), one white-tailed deer in 1937 (LeDune, 1937, as cited in Friend et al., 1963), and one white-tailed deer in 1961 (Friend et al., 1963). All deer were from the same area of New York (USA), which had a large dairy cattle population infected with $M$. bovis.

From 1970 to $1972, M$. bovis was isolated from tissues of three wild axis deer (Axis axis) and two wild cattle which ranged in the same area on the Hawaiian island of Molokai (USA) (Sawa et al., 1974). In subsequent years, a domestic cattle herd from the same area was found to be infected; and wildlife surveys disclosed a $20 \%$ prevalence of bovine tuberculosis in feral swine from the vicinity (Essey et al., 1983). Following depopulation of the cattle herd and an intense public hunting program, the prevalence of $M$. bovis infection in feral swine dropped to $3.2 \%$ by 1983 (Essey et al., 1983).

In Canada, tuberculosis was diagnosed in one free-ranging white-tailed deer in Ontario in 1958 (Belli, 1962). Gross lesions of tuberculosis were observed in 73 of 1,329 elk, six of 107 moose (Alces alces), and two of 242 mule deer killed in Buffalo National Park near Wainwright, Alberta, in 1939 and 1940 (Hadwen, 1942). This was concurrent with a disease prevalence of over $50 \%$ in the Buffalo National Park bison herd. In 1992, M. bovis was isolated from lesions from a single hunter-killed elk from Manitoba (G. W. Luterbach, pers. comm.). The elk was shot on property in proximity to an $M$. bovis-infected beef herd. No evidence of $\boldsymbol{M}$. bovis infection was found on subsequent examination and culturing of tissues from deer, elk, and moose from the area.

The occurrence of tuberculosis in this mule deer on property adjacent to an $M$. bovis-infected game ranch provides evidence for spread of the disease from captive cervids to the wild. Whether the deer acquired the infection on the premises and escape to the wild or became infected by contact through the fence with captive animals is unknown. It is noteworthy that although $M$. bovis lesions were present in the head and both body cavities of this deer, lesions were small and likely would not have been noticed without careful examination of lymph nodes of the head and viscera. Management plans include additional wildlife surveys, special public hunts, and elimination of the infected captive elk herd. These strategies will serve to eliminate the source of infection, better determine the prevalence of infection in area wildlife, and temporarily decrease the population density of area wildlife thereby reducing the chance for disease transmission. Further characterization of mule deer and game ranch isolates is in progress.

\section{LITERATURE CITED}

ANONYMOUS. 1994. Tuberculosis eradication in Cervidae: Uniform methods and rules. Animal and Plant Health Inspection Service, U.S. Department of Agriculture, Washington, D.C., p. 7.

BELLI, L. B. 1962. Bovine tuberculosis in a whitetailed deer (Odocoileus virginianus). Canadian Veterinary Journal 3: 356-358.

ESSEY, M. A., AND M. A. Koller. 1994. Status of bovine tuberculosis in North America. Veterinary Microbiology 40: 15-22.

$\longrightarrow$, AND C. D. STUMPFF. 1985. Report on the bovine tuberculosis outbreak in bison in the United States. Proceedings of the U.S. Animal Health Association Meeting 89: 450-457.

- D. E. Stallknecht, E. M. Himes, and S. K. HARris. 1983. Follow-up survey of feral swine for Mycobacterium bovis infection on the Hawaiian island of Molokai. Proceedings of the U.S. Animal Health Association Meeting 87: 589595.

Friend, M., E. T. Kroll, and H. Graft. 1963. Tuberculosis in a wild, white-tailed deer. New York Fish and Game Journal 10: 118-123.

HADWEN, S. 1942. Tuberculosis in the buffalo. Journal of the American Veterinary Medical Association 100: 19-22.

HENRY, E. J., AND D. R. CASSIDY. 1966. Rapid decalcification followed by a new fuchsin-methylene blue stain for acid-fast bacilli in frozen sections. Stain Technology 41: 345-346.

LEVINE, P. P. 1934. A report on tuberculosis in wild deer (Odocoileus virginianus). The Cornell Veterinarian 24: 264-266.

Payeur, J. B., J. L. Jarnagin, J. G. Marquardt, L. A. SChaper, AND B. M. MARTin. 1993. Laboratory methods in veterinary mycobacteriology for the isolation and identification of mycobac- 
teria. National Veterinary Services Laboratories, U.S. Department of Agriculture, Ames, Iowa, 117 pp.

RhYAN, J. C., AND D. A. SAARI. 1995. A comparative study of the histopathologic features of bovine tuberculosis in cattle, fallow deer (Dama dama), sika deer (Cervus nippon), and red deer and elk (Cervus elaphus). Veterinary Pathology 32: In press.

Sawa, T. A., C. O. Thoen, and W. T. Nagao. 1974.
Mycobacterium bovis infection in wild axis deer in Hawaii. Journal of the American Veterinary Medical Association 165: 998-999.

STUMPFF, C. D. 1982. Epidemiologic study of an outbreak of bovine TB in confined elk herds. Proceedings of the U.S. Animal Health Association Meeting 86: 524-527.

Received for publication 26 September 1994. 